\title{
Morphohistometric Evaluation of Embryonic Development of Spleen in Chicken
}

\author{
Fatma COLAKOGLU1, Muhammet Lutfi SELCUK² \\ ${ }^{1}$ Karamanoglu Mehmetbey University, Faculty of Health Sciences, Department of Nutrition and Dietetics, 70200, Karaman, Turkey \\ ${ }^{2}$ Karamanoglu Mehmetbey University, Faculty of Health Sciences, Department of Physiotherapy and Rehabilitation, 70200, Karaman, Turkey
}

\begin{abstract}
The aim of this study was to evaluate the morphohistometric development of chick spleen by considering specific embryonic periods. For the study, spleens obtained from 18 Babcock White Leghorn chick embryos on the $13^{\text {th }}$, $16^{\text {th }}$ and $21^{\text {st }}$ days of incubation were used. The sections were stained with Crossmon's trichrome stain and Pappenheim's panoptic stain and differential leukocyte counts were made in the blood smears. In the measurements, an increase in the spleen volume, embryo weight and vitellus sac weight were determined. There was an increase between the $13^{\text {th }}$ and $16^{\text {th }}-21^{\text {st }}$ days in spleen volume. The highest heterophil granulocytes $(74.83 \%)$ and lowest lymphocyte ratio $(23 \%)$ were found on the $21^{\text {st }}$ day. On the $13^{\text {th }}$ day, there were very few lymphocytes around the vessels. On the $16^{\text {th }}$ day, arteria centralis were frequently encountered and periarteriolar lymphoid tissue formation with lymphocyte accumulations around them started to develop in the spleen parenchyma. The red and white pulp areas could be easily distinguished in splenic parenchyma on the $21^{\text {st }}$ day. It was concluded that the structures characterised by lymphocyte infiltrations in the spleen parenchyma were formed and caused changes in the number of lymphocytes in peripheral blood during the embryonal period.
\end{abstract}

Key Words: Chicken, Embryonic Development, Spleen Morphohistometry, Spleen Volume

\section{Civcivlerde Dalağın Embriyonik Gelişiminin Morfohistometrik Değerlendirmesi}

\section{ÖZ}

Bu çalışmada, civcin dalağının belirli embriyonik dönemler göz önüne alınarak morfohistometrik gelişiminin değerlendirilmesi amaçlanmaktadır. Çalıșmada, kuluçkanın 13., 16. ve 21. günlerinde 18 Babcock White Leghorn civciv embriyosundan elde edilen dalaklar kullanıldı. Rutin histolojik incelemeler ve hacim hesaplamaları için doku kesitleri Crossmon trikrom boyası ve Pappenheim'ın panoptik boyası ile boyandı ve civciv embriyolarından alınan kan örneklerinden de formül lokösitleri çıkarıldı. Ölçümler sonucunda dalak hacminde, embriyo ağırlı̆̆ında ve vitellus kese ağırlığında bir artış tespit edildi. 13. ve 16.-21. günler arasında dalak hacminde fark tespit edildi. 21. gün kanındaki en yüksek lökosit oranı \% 74.83 ile heterofil granülositlerde gözlenirken; en düşük lenfosit oranı $\%$ 23 olarak bulundu. Kuluçka 13. günündeki dalak kesitlerindeki damarların etrafinda çok az sayıda lenfosit vardı. 16. gün kesitlerinin dalak paranşimasında sıklıkla arteryal centralis ile karşılaşıldı ve etraflarında lenfosit birikimli periarteriolar lenfoid doku oluşumunun gelişmeye başladığı görüldü. 21. günün dalak parankiminde kırmızı ve beyaz pulpa bölgelerinin kolayca ayırt edilmekteydi. Embriyonik dönemdeki dalağın parankiminde lenfosit infiltrasyonları ile karakterize edilen yapıların şekillendiği ve periferik kandaki lenfosit sayısında değişimlerin olduğu sonucuna varild.

Anahtar Kelimeler: Civciv, Embriyonik Gelişim, Dalak Morfohistometrisi, Dalak Hacmi

To cite this article: Colakoğlu A. Selcuk M.L. Morphohistometric Evaluation of Embryonic Development of Spleen in Chicken. Kocatepe Vet J. (2020) 13(4): 368-374.

Submission: 07.07.2020 Accepted: 12.11.2020 Published Online: 17.11.2020

ORCID ID; FC: 0000-0003-0410-5523, MLS: 0000-0002-9915-3829

*Corresponding author e-mail: mlselcuk@hotmail.com 


\section{INTRODUCTION}

The spleen, which has between-species morphological differences, is known as the largest peripheral lymphoid organ due to its function such as role in immunity, blood production, filtration and storage (Song et al. 2012). In chickens, the globular shaped spleen has an important role in the interaction of lymphoid and non-lymphoid cells in the incubation period of the poultry without lymph node due to their haematopoietic functions in the fetal period (Rajput et al. 2013). The development of embryonic spleen, which starts with mesenchymal cell accumulation in the first 48 hours of incubation, continues with the formation of sinusoiuds in mesenchymal tissue on the $5^{\text {th }}$ day of incubation. Erythropoiesis begins on the $7^{\text {th }}$ day of incubation and granulopoiesis starts on the $11^{\text {th }}$ day. Splenic development is completed in the first 10 weeks after incubation following antigenic stimulation (Olah and Vervelde 2008, Liman and Bayram 2011).

The spleen is surrounded by a capsule consisting of fibroelastic tissue, smooth muscle cells and has a closed circulation, but no trabecular structure is developed and there is also no marginal zone (Kannan et al. 2015, Khenenou et al. 2018, Aka and Eren 2019). Lienal artery continues as central artery in the pulp and branches to the penicillary arterioles into capillaries associated with venous sinuses (Olah and Vervelde 2008). The spleen is morphologically and functionally composed of white and red pulp regions. The white pulp is material made up of $\mathrm{T}$ and $\mathrm{B}$ lymphocyte deposits around arterioles and the red pulp is composed of spleen sinuses and spleen cords which are the area of blood filtering (Steiniger 2005,
Cesta 2006). In the white pulp of the chicken spleen, periarterial lymphoid tissue (PAL) or periarterial lymphoid sheath (PALS) is found around a. centralis, where $\mathrm{T}$ lymphocytes are located (Olah and Vervelde 2008, Liman and Bayram 2011). In addition, perivenous lymphoid tissue (PVL) around the vena, lymphoid tissue around the ellipsoid with dense B lymphocytes (PEL/PELT), subcapsular lymphoid tissue (SCL) under capsule and germinal centres (GC) with B lymphocyte regions are other structures seen in white pulp (Aka and Eren 2019). The germinal centres of the chicken spleen are seen only after antigenic stimulation and are located only as secondary follicles (Yasuda et al. 2003). The immune response to blood-borne antigen reactions starts with the white pulp area located around a. centralis (Cesta 2006). Lymphoid and non-lymphoid cells are found in the red pulp (Olah et al. 2012).

The aim of this study was to evaluate the morphohistometric development of the chick spleen by considering specific embryonic periods. It might be important in terms of creating a model for embryological studies in humans by using chick embryos during incubation.

\section{MATERIALS and METHODS}

For the study, spleens obtained from 18 Babcock White Leghorn chick embryos on the $13^{\text {th }}, 16^{\text {th }}$ and $21^{\text {st }}$ days of incubation were used. The research was approved by The Ethical Committee of Faculty of Health Sciences of Karamanoglu Mehmetbey University (2019/10-04).

First, the weights and pre-hatch weights of the eggs were recorded (Table 1). Then six embryos randomly

Table 1: Spleen volumes obtained using Cavalieri method and morphometric data (mean $\pm S D ; n=6$ )

\begin{tabular}{llll}
\hline & $\mathbf{1 3}^{\text {th }}$ day & $\mathbf{1 6}^{\text {th }}$ day & $\mathbf{2 1}^{\text {st }}$ day \\
\hline Spleen volume $\left.\mathbf{( m m}^{\mathbf{3}}\right)$ & $3.91 \pm 0.29^{\mathrm{b}}$ & $11.17 \pm 2.18^{\mathrm{a}}$ & $12.02 \pm 2.60^{\mathrm{a}}$ \\
Embryo weight $(\mathbf{g})$ & $8.91 \pm 0.46^{\mathrm{a}}$ & $22.74 \pm 2.71^{\mathrm{b}}$ & $41.41 \pm 2.33^{\mathrm{c}}$ \\
Egg weight $(\mathbf{g})$ & $59.85 \pm 3.89^{\mathrm{a}}$ & $58.03 \pm 5.50^{\mathrm{a}}$ & $56.07 \pm 3.74^{\mathrm{a}}$ \\
Pre-hatching egg weight $\mathbf{( g )}$ & $53.06 \pm 5.18^{\mathrm{a}}$ & $50.79 \pm 3.85^{\mathrm{a}}$ & $49.02 \pm 2.22^{\mathrm{a}}$ \\
Vitellus sac $(\mathbf{g})$ & $1.23 \pm 0.09^{\mathrm{b}}$ & $2.13 \pm 0.44^{\mathrm{a}}$ & $3.39 \pm 1.60^{\mathrm{a}}$ \\
Capsule thickness $(\boldsymbol{\mu m})$ & $8.93 \pm 3.17^{\mathrm{b}}$ & $17.74 \pm 5.29^{\mathrm{a}}$ & $21.43 \pm 12.39^{\mathrm{a}}$ \\
\hline
\end{tabular}

Different letters in the same row $(\mathrm{a}, \mathrm{b}, \mathrm{c})$ indicate statically significant differences $(\mathrm{p}<0.001)$.

selected in each group were fixed in buffered 10\% formal saline $(\mathrm{pH}$ 7.4) for a week, dehydrated in alcohol, cleared in xylene and paraffin blocks of spleens were prepared.

Serial tissue sections of $5 \mu \mathrm{m}$ were taken at regular intervals from paraffin blocks. Sampling was performed systematically and randomly at a ratio of $1 / 20$ by starting from a random one among the first 10 cross-sections and taking following every $20^{\text {th }}$ cross-section. As a result of systematic random sampling between 13 and 19 cross-sections were obtained from chick embryos spleens. For routine histological examinations and volume calculations, the sections were stained with Crossmon's trichrome stain (Selçuk and Tipırdamaz 2019) and Pappenheim's panoptic stain (Konuk 1981). The histological preparations were examined with a light microscope (Leica DM-2500 attached to a DFC-320 digital camera). Blood samples were also taken from the chick embryos on the $13^{\text {th }}, 16^{\text {th }}$ and $21^{\text {st }}$ days of the incubation and the prepared blood smears were stained with May Grünwald-Giemsa stain (Konuk 1981). Granulocyte production in poultry starts on the $11^{\text {th }}$ day of incubation and its development continues throughout incubation. Therefore, leukocyte separation could not be made on the $13^{\text {th }}$ 
and $16^{\text {th }}$ days. Blood samples were taken on the 21 st day to determine the peripheral blood leukocyte (PBL) ratio. To determine this ratio, 100 leukocyte cells were counted under a light microscope using a 100x objective lens and the leukocyte formula was determined.
Spleen volumes were calculated using a point area measurement scale $(\mathrm{d}=0.1 \mathrm{~mm})$ on the cross-sectional images taken at $4 \times$ lens magnification. Image programme was utilised for the calculations. In addition to the program, Cavalieri's principle was applied as calculation method (Figure 1).

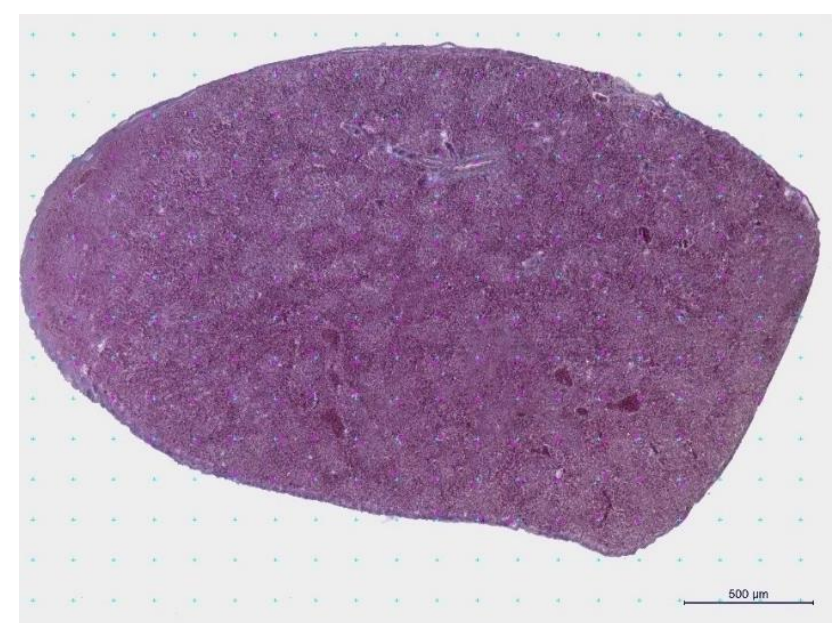

Figure 1. Application of point counting grid on histological sections of the spleen. Crossmon's trichrome stain (bar $=500 \mu \mathrm{m})$.

The volumes of the structures of interest in the sections were calculated using the formula $V=(a / p)$ $\times \sum \mathrm{P} \times \mathrm{t}$ (Mayhew and Gundersen 1996). In this formula, $\mathrm{V}=$ the volume of the structure of the sample of interest, $\mathrm{a} / \mathrm{p}=$ the area of a point in the point area measuring scale, $\sum \mathrm{P}=$ the total number of points on the structure of interest, $\mathrm{t}=$ average crosssectional thickness (Gundersen et al. 1999, Chen et al. 2012, Selcuk and Bahar 2014). Several methods are used for coefficient of error (CE) calculation stereological research. In this study, CE formula of Gundersen et al. (1999) was used.

Egg weight and pre-hatching egg weights were compared using Wilcoxon test. The difference between the groups was compared using Kruskal Wallis test. Statistical analysis was conducted with SPSS software version 21.0. $\mathrm{P}<0.05$ was accepted statistically significant. Data are expressed as means \pm standard deviation (SD).

\section{RESULTS}

The spleen volumes obtained using Cavalieri's method and some morphometric data of the chicks are given in Table 1 . As a result of the measurements, an increase in the spleen volume, embryo weight and vitellus sac weight were determined as the hatching time of the chicks approached and a decrease in egg weights was detected. There was a significantly statistical difference $(p<0.001)$ between $13^{\text {th }}$ and $16^{\text {th }}-21^{\text {st }}$ days in spleen volume increase, whereas no difference between $16^{\text {th }}$ and $21^{\text {st }}$ days was noted . The mean CE values for $13^{\text {th }}, 16^{\text {th }}$ and $21^{\text {st }}$ day were determined as 0.017, 0.007 and 0.012, respectively.
When the egg weight and pre-hatching egg weight measurements were compared, it was found that weight decreased towards the $21^{\text {st }}$ day $(p<0.05)$. Spleen capsule thickness was found to be increased, and it was found to be statistically different between $13^{\text {th }}$ and $16^{\text {th }}-21^{\text {st }}$ days.

As a result of microscopic blood examination, it was observed that granulocytes were predominantly lymphocytes on the $13^{\text {th }}$ day of the incubation, whereas the number of heterophil granulocytes was higher than that of lymphocytes on the $16^{\text {th }}$ day. On the $13^{\text {th }}$ and $16^{\text {th }}$ days, there were erythrocytes in various stages of development. According to the PBL counts on the 21st day of incubation, the highest heterophil granulocytes and lowest lymphocyte ratio were found as $74.83 \%$ and $23 \%$, respectively (Fig. 2; Table 2).

On the $13^{\text {th }}$ day of incubation, there were very few lymphocytes around the vessels (Fig. 3). On the $16^{\text {th }}$ day of incubation, spleens from embryos were surrounded by a developing thin capsule. Smooth muscle cells and vascularisation in the capsule could not be seen clearly. A trabecular structure extending from the capsule to the splenic parenchyma but not developed in the parenchyma was detected. Trabecular vien and artery was found in connective tissue. In the parenchyma, central artery was frequently encountered and it was seen that PAL formation with lymphocyte accumulations around them started to develop. It was also observed that PEL formations (lymphoid deposits around ellipsoid structures and ellipsoid capillaries,) were developing in white pulp areas. The presence of venous sinuses showed that the red pulp was also developing vessels 
(Fig. 4). The embryonal development of the spleens was completed on the $21^{\text {st }}$ day of incubation. The spleen capsule consisting of fibrous connective tissue increased significantly compared to the $16^{\text {th }}$ day. The smooth muscle cells in the capsule were easily visible and denser. Vascularisation was more advanced than on day $16^{\text {th }}$ and connective tissue from the capsule into the splenic parenchyma contained an undeveloped trabecular structure as well as trabecular vessels. Lienalis ramus and lineal vena were found in the connective tissue outside the capsule. The most significant change in the splenic parenchyma was that the red and white pulp areas could be easily distinguished. PEL formation around the ellipsoid capillaries along with the dense lymphocytecontaining PAL regions around the central artery were clearly seen in the white pulp. The ellipsoid structures in the parenchyma could be observed easily. In addition, SCL formed by lymphocyte accumulations under the capsule and PVL around the vena were also found out (Fig. 5).

Table 2: Proportions of peripheral blood leukocyte on $21^{\text {st }}$ day of the incubation (\%). Data are presented as mean $\pm \mathrm{SD}(\mathrm{n}=6)$

\begin{tabular}{ll}
\hline Leukocyte types & \\
\hline Lymphocyte & $23.00 \pm 1.39$ \\
Heterophil & $74.83 \pm 1.99$ \\
Monocyte & $1.17 \pm 0.40$ \\
Eosinophil & $1.67 \pm 0.21$ \\
Basophil & $0.67 \pm 0.21$ \\
\hline
\end{tabular}

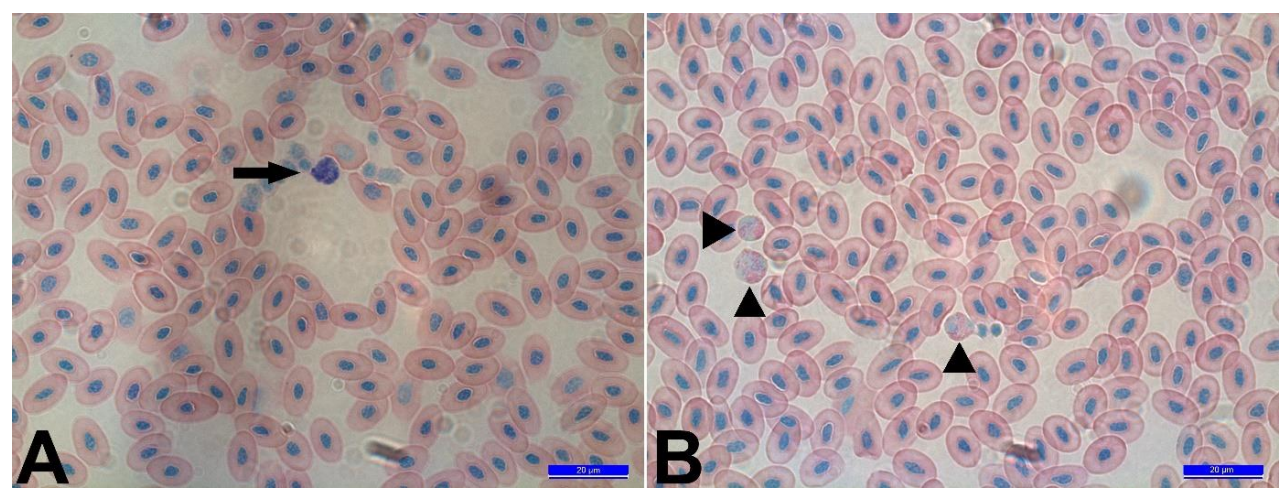

Figure 2. Peripheral blood smear of an embryo on the $21^{\text {st }}$ day of incubation. A. Lymphocyte $(\rightarrow)$; B. Heterophil leukocytes $(\triangleright)$. May Grünwald-Giemsa stain (bar $=20 \mu \mathrm{m})$.

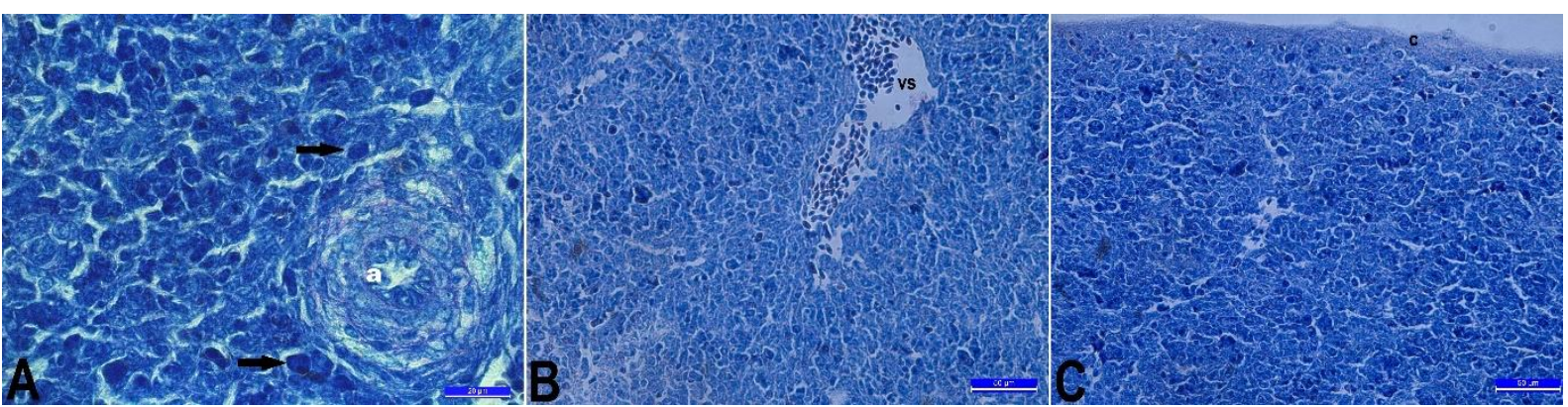

Figure 3. Spleen section of an embryo on the $13^{\text {th }}$ day of incubation. Pappenheim's panoptic stain. A: Central artery (a), lymphocytes $(\rightarrow)$ (bar=20 $\mu \mathrm{m})$. B: venous sinus (vs); C: capsule (c) (bar=50 $\mu \mathrm{m})$. 


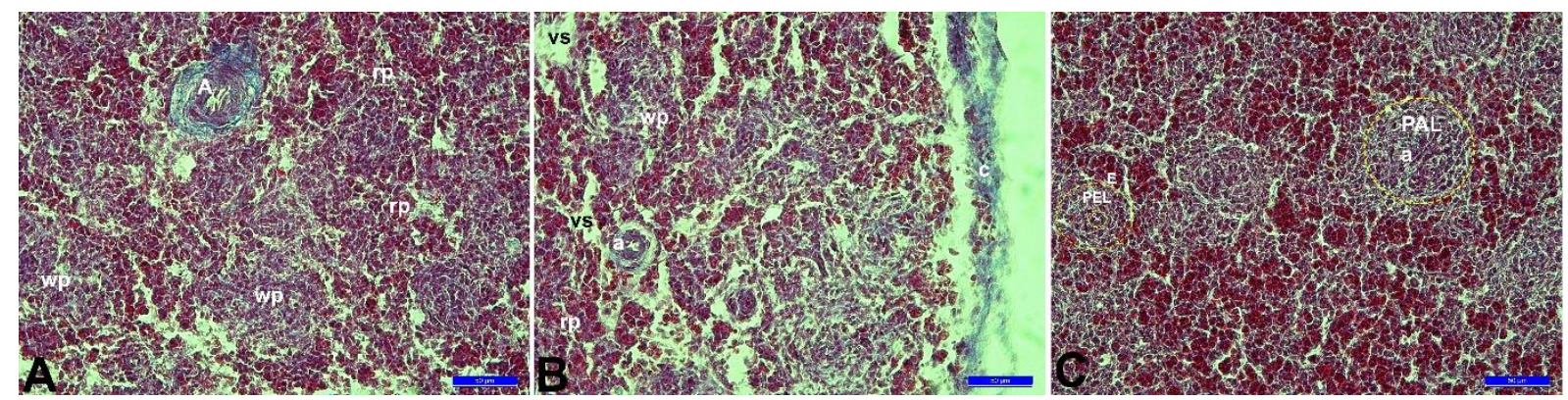

Figure 4. Spleen section of an embryo on the 16 th day of incubation. Crossmon's trichrome stain. A: Trabecular artery (A), red pulp (rp), white pulp (wp). B: Venous sinus (vs), red pulp (rp), white pulp (wp), central artery (a), capsule (c). C: central artery (a), ellipsoid (E), PAL and PEL regions (bar $=50 \mu \mathrm{m})$.
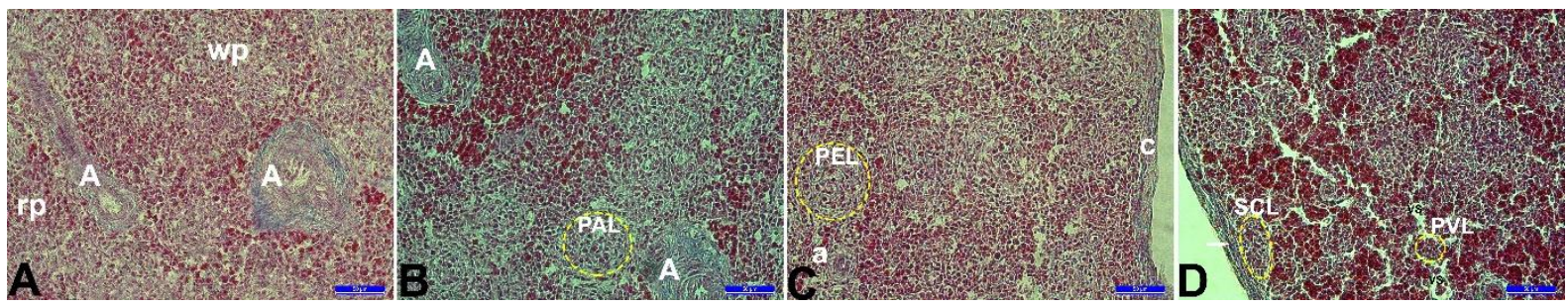

Figure 5. Spleen section of an embryo on the $21^{\text {st }}$ day of incubation. Crossmon's trichrome stain. A: Trabecular artery (A), red pulp (rp), white pulp (wp); B: Trabecular artery (A), PAL; C: Central artery (a), capsule (c), PEL region; D: SCL and PVL regions, venous sinus (vs) (bar $=50 \mu \mathrm{m})$.

\section{DISCUSSION}

Spleen, the largest lymphoid organ of poultry without lymph nodes, is known as a secondary lymphoid organ in which $\mathrm{T}$ and $\mathrm{B}$ lymphocytes are located (Aka and Eren 2019). Immune response is accepted as a production site (Steiniger 2005). Morphological and histological structures show differences depending on age, genetics and species. The spleen is oval in ostriches, triangular in ducks and globular in chickens (Cesta 2006, Song et al. 2012). Song et al. (2012) reported that the ostrich spleen was dark red, elliptical, and was located tightly to the posterior of the proventriculus, vena caudalis and the right kidney. Khenenou et al. (2018) reported that the spleen reached maximum size in the first six weeks after incubation. Some studies have reported that the spleen grows rapidly in the first six weeks after incubation and reaches maximum size at 10 weeks (Olah and Vervelde 2008, Liman and Bayram, 2011). In this study, globular-shaped chick embryonal spleens were located between the proventriculus and the posterior of the vena caudalis.

As a result of the measurements, an increase in the spleen volume, embryo weight and vitellus sac weight was determined as the hatch time of the chicks approached. Increased spleen volume and embryo weight could be explained by the development and growth of the chick. The increase in the weight of the vitellus sac was thought to be due to the fact that the vitellus sac consisting of endoderm was initially covered with splanchnic mesoderm and the development of blood vessels on the vitellus. It was determined that egg weights decreased as the hatching time of the chicks approached. The reason for this was thought to be that the nutrients contained in the egg were burned with oxygen and converted into carbon dioxide and water and thrown out of the egg.

The foetal spleen begins to form as an accumulation of primitive reticular cells in the dorsal mesogastrium (Cesta 2006). Seymour et al. (2006) found the first splenic tissue in mice on 12.5 days of pregnancy and the first haematopoietic cells on 15.5 days of pregnancy. In this study, it was found that in the spleen parenchyma small number of lymphocyte began to infiltrated the spleen on the $13^{\text {th }}$ day of incubation. On the $13^{\text {th }}$ day, peripheral blood was predominantly lymphocytic. On the $16^{\text {th }}$ day, the number of lymphocytes in the circulating blood decreased; however, lymphocyte infiltrations in the spleen parenchyma and white pulp started to develop. On the $21^{\text {st }}$ day of the incubation, where the two pulp separations were made clearly and the structures characterised by lymphocyte accumulation were easily seen, the percentage of lymphocytes in the peripheral blood was found to be low. This was probably due to the migration of lymphocytes into the spleen parenchyma.

There is no real trabecular structure in the winged spleen wrapped with a thin capsule (Olah and Vervelde 2008, Liman and Bayram 2011, Bingöl et al. 
2014, Khenenou et al. 2018). Song et al. (2012) reported that the spleen membrane thickness in ostriches was 25.0-41.5 $\mu \mathrm{m}$ and undeveloped spleen trabeculae were encountered. In this study, it was seen that the thickness of the capsule covering the spleen from the $13^{\text {th }}$ day to the $21^{\text {st }}$ day of the incubation increased. The spleen membrane, which was $8.93 \pm 3.17 \mu \mathrm{m}$ thick on $13^{\text {th }}$ day, reached $17.74 \pm 5.29 \mu \mathrm{m}$ on $16^{\text {th }}$ day and $21.43 \pm 12.39 \mu \mathrm{m}$ on $21^{\text {st }}$ day. The density of smooth muscle cells in the capsule was also proportional to the thickness of the spleen membrane.

The parenchyma of the spleen consists of white and red pulp areas with unclear borders (Song et al. 2012, Khenenou et al. 2018, Aka and Eren, 2019). In this study, it was observed that lymphocyte accumulation gradually increased in the spleen on the $13^{\text {th }}$ day of incubation. From the $16^{\text {th }}$ day of incubation, it was seen that the separation of white and red pulp was clear. It was observed that PAL gradually expanded with lymphocyte infiltration and this ratio was found to be larger in the spleens on the $21^{\text {st }}$ day compared to the other days.

The first cells in the foetal spleen are haematopoietic cells (Cesta 2006). Spleen migration of $T$ and $B$ lymphocytes start on the $52^{\text {nd }}$ day of pregnancy in dogs, $120^{\text {th }}$ day on horses, and 13th-14th days of incubation on chickens (HoganEsch and Hahn 2001). The first lymphocytes seen are $\mathrm{T}$ lymphocytes that accumulate in the PALS region (Van Rees et al. 1996). Sur and Celik (2004) reported that they were encountered in a large number of haemopoietic foci in the spleen on the $12^{\text {th }}$ day of incubation and a small number of lymphocytes located in the tunica adventitia floor of the small arteries and that white pulp development became more prominent with lymphocyte infiltration on the $13^{\text {th }}$ day of incubation. On the $15^{\text {th }}$ day of incubation, more advanced lymph follicles were observed; on the $18^{\text {th }}$ day, it was stated that there was a rich stroma of reticular network with prominent white and red pulp areas. It is reported that the histological development of the spleens on the first day of hatching was complete and the germinal centres are formed. The data obtained from Sur and Çelik (2004) were similar to those found in our study. Lymphocyte infiltration and the development of white pulp was detected in the spleens on the $16^{\text {th }}$ day. Arterial, arteriole, capillary, venous sinuses and ellipsoid structures were encountered and developing PAL were clearly identified. At the time of incubation, spleens completed embryonic development and the presence of white and red pulp areas was easily seen in all sections.

Penicillary capillaries with endothelial cells and reticular cells form ellipsoid and this structure acts as a filter apparatus. The ellipsoid-associated cells (EACs), which are phagocytic cells, are of blood origin and are located in the antigen-spanning region of the chicken spleen (Igyarto et al. 2007, Song et al. 2012, Aka and Eren 2019). Kannan et al. (2015) reported that there were a few macrophages in EACs. White pulp in chicken spleen consists of five different parts. These are PAL, PVL, PEL, SCL and GC (Liman and Bayram 2011, Aka and Eren 2019). GCs of chicken spleen are seen only after antigenic situmulation and are considered as secondary follicles (Yasuda et al. 2003). In this study, it was seen that PAL, PEL, PVL and SCL regions started to take shape in spleen sections taken from $16^{\text {th }}$ day embryos and these structures were more advanced on the $21^{\text {st }}$ day. Since there was no antigenic stimulation, GCs were not formed in the primary follicles.

The formation of structures characterised by lymphocyte infiltrations in the parenchyma of the spleen in the embryonal period also led to changes in the lymphocyte counts in the peripheral blood. Depending on the embryonic development, parts such as PAL/PALS, PEL/PELT, PVL, and SCL were found to form the white pulp, but no GCs were detected because the spleen did not encounter any antigenic stimulation. Therefore, it was concluded that the spleen completed its embryonic development but its immunological development was not fully completed.

Conflict of Interest: The authors declare that they have no conflict of interest

\section{REFERENCES}

Aka E, Eren Ü. Kuluçka sonrası ilk iki haftada lipopolisakkarit uygulanan ve uygulanmayan broyler civcivlerde dalağın histolojik gelişimi. Erciyes Üniv Vet Fak Derg. 2019; 16(1):8-15.

Bingöl SA, Gülmez NY, Deprem T, Taşci SK, Aslan Ş. Histologic and histometric examination of spleen in geese (Anser anser). Atatürk University J Vet. 2014; 9(3):157162.

Chen X, Zhao H, Yao J. A fully automated framework for renal cortex segmentation, In: Abdominal Imaging, ed; Yoshida H, Hawkes D, Vannier MW, Springer, Berlin. 2012; pp. 208-217.

Cesta MF. Normal structure, function, and histology of the spleen. Toxicol Pathol. 206; 34:455-465.

HoganEsch H, Hahn FF. The Lymphoid organs: Anatomy, development, and age-related changes, In: Pathobiology of the Aging Dog, ed; Mohr U, Carlton WW, Dungworth DL, Benjamin SA, $1_{\text {st }}$ Ed., Iowa State University Press, Ames. 2001; pp. 127-135.

Gundersen HJ, Jensen EB, Kieu K, Nielsen J. The efficiency of systematic sampling in stereology reconsidered. J Microsc. 1999; 193:199-211.

Igyarto BZ, Magyar A, Olah I. Origin of follicular dendritic cell in the chicken spleen. Cell Tissue Res. 2007; 327:83-92. 
Kannan TA, Ramesh G, Ushakumari S, Dhinakarraj G, Vairamuthu S. Electron microscopic studies of spleen in chicken (Gallus domesticus). IJAVST. 2015; 4(1):160-165.

Khenenou T, Berghiche A, Rahmoun DE, Berberis A. Morpho histological study of the spleen of broiler chickens during post-haching age. IJVSAH. 2018; 3:22-23.

Liman N, Bayram GK. Structure of the quail (Coturnix coturnix japonica) spleen during pre- and post-hatching periods. Rev Med Vet. 2011; 162:25-33.

Mayhew T, Gundersen $\mathbf{H}$. If you assume, you can make an ass out of $\mathrm{u}$ and me: a decade of the disector for stereological counting of particles in 3D space. J Anat. 1996; 188:1-15.

Olah I, Vervelde L. Structure of the avian lymphoid system, In: Avian Immunology, Ed; Davison F, Kaspers B, Schat K, Academic Press, London. 2008; pp. 13-50.

Olah I, Nagy N, Vervelde L. Structure of the avian lymphoid system, In: Avian Immunology, Ed; Schat KA, Kaspers B, Kaiser P, $2_{\text {nd }}$ eEd., Academic Press, London. 2014; pp. $11-43$.

Selcuk ML, Bahar S. The morphometric properties of the lumbar spinal cord segments in horses. J Anim Vet Adv. 2014; 13:653-659.

Selçuk ML, Tıpırdamaz S. A morphological and stereological study on brain, cerebral hemispheres and cerebellum of New Zealand rabbits. Anat Histol Embryol. 2020; 49:90_ 96.

Seymour R, Sundberg JP, Hogenesch H. Abnormal lymphoid organ development in immunodeficient mutant mice. Vet Pathol. 2006; 43:401-423.

Song $\mathrm{H}$, Peng $\mathrm{K}$, Li S, Wang $\mathrm{Y}$, Wei L, Tang $\mathrm{L}$. Morrphological characterization of the immune organs in ostrich chicks. Turk J Vet Anim Sci. 2012; 36:89-100.

Steiniger, B., 2005. Spleen. In: Encyclopedia of Life Sciences, John Wiley \& Sons, pp. 1-9.

Sur E, Çelik İ. Yumurtaya verilen aflatoksin B1'in tavuk dalağının embriyonik gelişimi üzerindeki etkileri: histolojik bulgular. Vet Bil Derg. 2004; 20:103-110.

Rajput IR, Wu BB, Li LY, Xu X. Establishment of optimal culturing method and biological activity analysis of chicken bone marrow dendritic cells using Chi-rGM-CSF. IJAB. 2013; 15:401-409.

Van Rees EP, Sminia T, Dijkstra CD. Structure and development of the lymphod organs, In: Pathobiology of the Aging Mouse, Ed; Mohr U, Dungworth CC, Capen CC, CarltonWW, $1_{\text {st }}$ Ed., ILSI Press, Washington. 1996; pp. 173-187.

Yasuda M, Kajiwara E, Ekino S, Taura Y, Hirota Y, Horiuchi H, Matsuda H, Furusawa S. Immunobiology of chicken germinal center: I. Changes in surface Ig class expression in the chicken splenic germinal center after antigenic stimulation. Dev Comp Immunol. 2003; 27:159-166. 